\author{
Military Technical College \\ Kobry Elkobbah, Cairo, \\ Egypt.
}

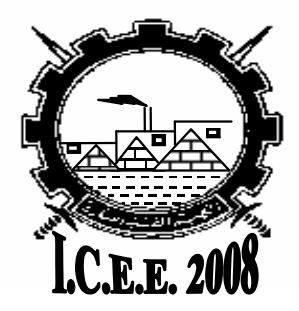

$4^{\text {th }}$ International Conference On Chemical \& Environmental Engineering 27-29 May 2008

\title{
THE EFFECT OF pH ON THE SYNTHESIS \\ OF HYDROXYAPATITE BY A NEW POLYMERIZED ORGANIC- INORGANIC COMPLEX ROUTE
}

\author{
Waffa* I. A., Fayed $^{\star *}$ M. Sh., Gouda*** Sh. R., Awwad ${ }^{\star *}$ S. A.
}

\begin{abstract}
A new polymerized organic-inorganic complexation route was used in the synthesis of hydroxyapatite (HAp). A simple structure and inexpensive polymer, polyvinyl alcohol (PVAL), was used as the organic carrier for precursor ceramic gel. Hydroxyapatite - polyvinyl alcohol -gel nanocomposite was synthesized and characterized via FTIR, SEM and XRD. The effect of $\mathrm{pH}$ on the synthesis of hydroxyapatite was studied by FTIR and SEM analyses of the synthetic powder to achieve apatite form. The PVAL content and its degree of polymerization had a significant influence on the homogeneity of hydroxyapatite gelatin nanocomposites. Various calcium phosphates structures were achieved by controlled $\mathrm{pH}$ values.
\end{abstract}

\section{KEY WORDS}

Polyvinyl alcohol, Hydroxyapatite, Gelation, Nanoparticle.

\footnotetext{
* National Research Centre.

** Egyptian Military Forces.

*** Elmaadi Modern Academy
} 


\section{INTRODUCTION}

Calcium phosphate based bioceramics, mainly in the form of hydroxyapatite (HAp), have been used in medicine and dentistry for the last 20 years. Hydroxyapatite, stoichiometric hydroxyapatite $\mathrm{Ca}_{5}(\mathrm{OH})\left(\mathrm{PO}_{4}\right)_{3},(\mathrm{HAp})$, which is well known as the mineral constituent of heart tissues bones, teeth, is of importance in many biomedical fields as in repair of bony defects [1], periodontal defects, ear implants [2], dental implants[3], as powders in total hip and knee surgery[4]; and in the industrial applications, such as gas sensor [5], removal of heavy metals [6], fuel cell [7], electronic and optical filters [8], dose indicators [9], liquid chromatography [10], agriculture [11-12], catalysis and ion exchange. Furthermore, HAp also has the ability to absorb organic chemicals [13]. These applications stimulate to develop new methods to synthesis HAp materials.

A simple structure and inexpensive polymer, polyvinyl alcohol (PVAL), was used as the polymeric carrier [14-15]. Nitrates ions, as cation sources for oxide ceramic powders, become oxidizing agents for the decomposition of PVAL. The PVAL operates as a steric entrapment mechanism in the organic-inorganic solution, due to its large chain molecule. The properties of PVAL depend on its degree of polymerization, degree of hydrolysis, and distribution of hydrolyzed groups. The hydroxyl groups hinder the solubility due to strong hydrogen bonding between the intra-and intermolecular $\mathrm{OH}$ groups.

Synthetic polymer-HAp composites are derived by preparing HAp in polymeric media (polymer matrix) without any chemical interaction between organic-inorganic interface. This leads to formation of $\mathrm{HAp}$ in nanoscale. $\mathrm{pH}$ is an important factor to get apatite form [16]. Also the metal ion-ligand complex based polymer precursors, which is very suitable for complex mixed oxide systems and in using for complexing agent to keep homogeneous distribution of metal ions through the matrix [17].The advantages of organic-inorganic complex route are low the processing temperature, molecular level homogeneity, improved purity, morphology, texture, and scope for tailor made compound.

In this study, the effect of $\mathrm{pH}$ on the synthesis of hydroxyapatite prepared by poly vinyl alcohol was investigated.

\section{EXPERIMENTAL}

\section{1-Chemicals}

The source, origin and specifications of the used chemicals are listed in Table(1).

They were used in the experimental work without further purification.

\section{2-Instrumentation}

The morphology and microstructure of the prepared samples was fulfilled with Philips XL30 scanning electron microscope. The powder sample was placed on double face 
carbon adhesive tape fixed in the microscope vacuum chamber. After complete evacuated of the chamber, an electron beam was generated till the sample picture was clear on the computer screen.

The infrared spectra of the prepared samples were obtained by using Mattson Infinity Series FTIR, in the wave number range from $400-4000 \mathrm{~cm}^{-1}$ using the $\mathrm{KBr}$ disc technique. A $198 \mathrm{mg}$ of very fine grinding and dried $\mathrm{KBr}$ mixed with $2 \mathrm{mg}$ of a sample. The mixture was placed in a special die compressed with hydraulic press for $15 \mathrm{~min}$, under $5000 \mathrm{PSI}$ in a vacuum press to form a transparent disc. While the phase analysis of the prepared samples after drying and grinding, through hand grinding, were detected using X-ray diffractometer Philips PW 1390 at a scanning speed of $2 .=2 \%$ min with CuK target and Ni filter ( =1.5404 $\AA$ ).

\section{3- THE PREPARATION OF HYDROXYAPATITE:}

A 5\% PVAL were prepared in 1-L flat bottom flask (dissolved in deionized water) while stirring and heated at $80^{\circ} \mathrm{C}$ for $30 \mathrm{~min}$. After complete dissolution of PVAL the calcium nitrate $\left(\mathrm{Ca}\left(\mathrm{NO}_{3}\right)_{2} \cdot 4 \mathrm{H}_{2} \mathrm{O}\right)$ was added while stirring and heating until complete dissolution Finally diammonium hydrogen ortho phosphate $\left(\left(\mathrm{NH}_{4}\right)_{2} \mathrm{HPO}_{4}\right)$ was added to the mixture with $\mathrm{Ca} / \mathrm{P}$ atomic ratio 1.67 while stirring and heating at $80^{\circ} \mathrm{C}$. The final solution was concentrated by evaporation. The produced gel was filtrated and washing 6 times with deionized water and dried at $100^{\circ} \mathrm{C}$ for $24 \mathrm{hr}$. Preliminary experiments were carried out to investigate the parameters affecting the synthesis to achieve HAp form, (concentration of PVAL, Ca/P ratio, heating temp., $\mathrm{pH}$, stir., adding technique,...etc). Fig. 1 shows the flow chart of the selected conditions for preparation from our investigation analysis

If the concentration of polyvinyl alcohol is more than $5 \%$, the viscosity of the solution increased and that will make the filtration too difficult also it was found that after complete dissolution of calcium nitrate in deionized water, the calcium nitrate was added to PVAL, then ammonium phosphate $\left.\left(\mathrm{NH}_{4}\right)_{2} \mathrm{HPO}_{4}\right)$ was added drop by drop to the reactant mixture. The addition of ammonium phosphate before calcium salt lead to the formation of undesirable white precipitate; while a white gel was formed by pouring phosphate directly after calcium nitrate addition. After the product was concentrated in the last stage, the $\mathrm{pH}$ of the solution was changed from its final value until reach $\mathrm{pH}$ of values $5,9,11$ and 14 using ammonium hydroxide to get apatite form [16]. The produced samples were characterized by FTIR, SEM and XRD.

\section{RESULTS AND DISCUSSION}

The IR spectra of hydroxyapatite have two bands at 3570 and $630 \mathrm{~cm}^{-1}$ which are assigned to the stretching and hindered rotation modes of apatite hydroxyl $(\mathrm{OH})$ group, respectively. The $\mathrm{OH}$ stretching vibration is unique for crystalline HAp and its intensity is considerably weaker compared to the strong $\mathrm{P}-\mathrm{O}$ stretching vibration because of the HAp stoichiometry $[18,19]$. The $\mathrm{C}-\mathrm{CH}_{2}$ asymmetric bending of PVAL with its corresponding peak at $2071 \mathrm{~cm}^{-1}$ was disappeared. That's mean there was no presence of PVAL in the sample after washing and drying. Fig. 2 shows the IR 
spectra of samples which were prepared at different $\mathrm{pH}$ values $5,8,9,11$ and 14 dried at $100^{\circ} \mathrm{C}$ for $24 \mathrm{hr}$.

The characteristic bands of dicalcium phosphate (Brushite $\mathrm{Ca}_{2}\left(\mathrm{HPO}_{4}\right)_{2} .2 \mathrm{H}_{2} \mathrm{O}$ ) were appeared at $\mathrm{pH} 5$; while in Fig. $2 \mathrm{~b}, \mathrm{c}$ and $\mathrm{d}$, the characteristic bands of HAp $\mathrm{Ca}_{10}\left(\mathrm{PO}_{4}\right)_{6}(\mathrm{OH})_{2}$ were appeared at the samples which were prepared at $\mathrm{pH} 8,9$ and $\mathrm{pH} 11$ Fig. 2b, 2c and 2d respectively [13]. The two bands at 630 and $3570 \mathrm{~cm}^{-1}$ belong to the vibration of hydroxyl $\mathrm{OH}$ are gradually appeared. Those bands at 1036, 1091 and $963 \mathrm{~cm}^{-1}$ are the characteristic bands of phosphate $\mathrm{PO}_{4}{ }^{3-}$ stretching vibration, while the bands at 603 and $565 \mathrm{~cm}^{-1}$ are due to phosphate bending vibration. From these measurements, the precipitate particle is proved to be hydroxyapatite formed at $\mathrm{pH}$ value 8 up to 11 .

At higher $\mathrm{pH}$ value (14), Fig. $2 \mathrm{e}$, the characteristic peaks of phosphate dose not appears. This may be due the increase of percentage of the ammonium hydroxide in the media The X-ray diffraction patterns of the sample prepared at $\mathrm{pH} 5$ Fig. 3 showed the appearance of dicalcium phosphate (Brushite $\left.\mathrm{Ca}_{2}\left(\mathrm{HPO}_{4}\right)_{2} \cdot 2 \mathrm{H}_{2} \mathrm{O}\right)[20]$, while at $\mathrm{pH} 8$ the XRD patterns show the prepared sample of hydroxyapatite [21] without any other sample of calcium phosphate structure in Fig. 4. The XRD patterns verified the IR spectra of the prepared samples at $\mathrm{pH} 5$ and $\mathrm{pH} 8$.

Morphological investigations of the powders after drying for $24 \mathrm{hr}$ at $100^{\circ} \mathrm{C}$ at different $\mathrm{pH}$ values were shown in Fig. 5. A needle like particles closed to each other form as flakes were appeared at $\mathrm{pH} 5$, Fig. $5 \mathrm{a}$, and the agglomeration of the particles increased as $\mathrm{pH}$ increases until reach 9 to form small blocks of tubular shape at $\mathrm{pH} 9$ Fig. 5c, and neck was formed between these grains to form large flakes, Fig. $5 d$ and $5 \mathrm{e}$. The average grain dimensions increases as $\mathrm{pH}$ values increases from $5 \mathrm{~m}$ until $20 \mathrm{~m}$. while the morphology analysis of the sample was prepared via PVA method and calcined at $900^{\circ} \mathrm{C}$ for $6 \mathrm{hrs}$ at $\mathrm{pH} 8$, showed a very small fused grains contacted with each other formed as rod shapes and the average particle size is 20 40nm Fig.6.

\section{CONCLUSION}

An inexpensive polymer polyvinyl alcohol was used in a simple technique for the preparation of different calcium phosphates structures by control the $\mathrm{pH}$ values. The advantages of this technique, low processing temperature, molecular level homogeneity, improved purity, morphology,....etc. Pentacalcium hydroxyl Apatite (Hydroxyapatite $\mathrm{Ca}_{10}\left(\mathrm{PO}_{4}\right)_{6}(\mathrm{OH})_{2}$ ) was obtained at $\mathrm{pH}$ values from 8-11 while dicalcium phosphate $\left(\right.$ Brushite $\left.\mathrm{Ca}_{2}\left(\mathrm{HPO}_{4}\right)_{2} \cdot 2 \mathrm{H}_{2} \mathrm{O}\right)$ was obtained at $\mathrm{pH}$. The average grain size of hydroxyapatite calcined at $900^{\circ} \mathrm{C}$ for $6 \mathrm{hrs}$ is $20-40 \mathrm{~nm}$ with a well crystalline shape. 


\section{REFERENCES}

[1] T. Nakano, A. Tokumura and Y. Umakoshi, "Variation in crystallinity of hydroxyapatite and the related calcium phosphates by mechanical Grinding and Subsequent Heat Treatment", Metallurgical and materials transactions A, Vol. 33A, p.521, (2002).

[2] D. Tadic and M. Epple, "A thorough physicochemical characterization of 14 calcium phosphate-based bone substitution materials in comparison to natural bone", Biomaterials Vol.25, pp 987-994, (2004).

[3] R. LeGeros, "Calcium phosphate ceramics in dentistry and medicine", Department of Metallurgy and Materials Engineering, Institute of Materials Science, University of Connecticut, Seminar Series, USA,(2002).

[4] S. Pathumarak, C. Lorprayoon and W. Intiya, "Preparation and characterization of porous hydroxyapatite from Bovine bone used as bone substitute materials", 26th Congress on Science and Technology of Thailand, Bangkok, (2000).

[5] H. Owada, K. Yamashita, T. Umegaki, T. Kanazawa and M. Nagai, "Humiditysensitivity of yttrium substituted apatite ceramics", Solid State lonics, Vol. 35, pp 401-404, (1989).

[6] W. Bostick and R. Stevenson, "Use of apatite and bone char for the removal of soluble radionuclides in authentic and simulated DOE groundwater", Advances in Environmental Research, Vol. 3, pp 488-498, (2000).

[7] Y. Park and Y. Yamazaki, "The development of high crystalline calcium phosphate/nafion composite membrane for fuel cell", $1^{\text {st }}$ International Conference on Polymer Batteries and Fuel Cells, Korea, (2003).

[8] J. Goes, N. Aranha, I. Vasconcelos and A. Sombra; "Collagen-Hydroxyapatite Films: Piezoelectric Properties", Second International Conference on Inorganic Materials, Santa Barbara/CA, USA, September (2000).

[9] D. Schramm and A. Rossi, "Electron spin resonance (ESR) studies of $\mathrm{CO}_{2}$ radicals in irradiated $\mathrm{A}$ and B-type carbonate-containing apatites", Applied Radiation and Isotopes, Vol. 52, pp 1085-1091, (2000).

[10] Z. Liu, G. Yin, Sh. Feng, D. Wang, F. Ding and N. Yuan, "Oscillatory electroosmosis-enhanced intra / inter-particle liquid transport and its primary applications in the preparative electrochromatography of proteins", Journal of Chromatography A, Vol. 921, pp 93-98, (2001).

[11] B. Tardy, R. Bricka and S. Larson, "Chemical stabilization of lead in small arms firing range soils", Environmental Quality and Technology Program, p. 13, September (2003).

[12] K. Moriyama, T. Kojima, Y. Minawa, S. Matsumoto and K. Nakamachi, "Development of artificial seed crystal for crystallization of calcium phosphate", Environmental Technology, Vol. 22. pp 1245-1252, (2001).

[13] Y. Liu , W. Wang, Y. Zhan ,Ch. Zheng and G. Wang, "A simple route to hydroxyapatite nanofibers", Materials Letters, Vol. 56, pp 496-501 (2002).

[14] S. Lee, E. Benson and W. Kriven, "Preparation of portland cement components by PVA solution polymerization”, J. Am. Ceram. Soc. Vol.82 No.8, pp 20492055 (1999).

[15] M. Nguyen, S. Lee and W. Kriven, "Synthesis of oxide powders via a polymeric steric entrapment precursor route", J. Mater. Res., Vol.14, No.8, pp 3417-3426 (1999).

[16] A. Ravaglioli and A. Krajewski, "Bioceramics: materials, properties and applications", Chapman and Hall, U.K, (1992). 
[17] P. Pramanik, "Soft chemicals for high-tech materials", Department of chemistry, Indian institute of technology, Kharagpur, India, (2003).

[18] F. Chen, Z. Wang and C. Lin, "Preparation and characterization of nano-sized hydroxyapatite particles and hydroxyapatite/chitosan nano-composite for use in biomedical materials", Materials Letters, Vol. 57, pp 858-861, (2002).

[19] S. Padilla, M. Vallet, M. Ginebra and F. Gilb, "Processing and mechanical properties of hydroxyapatite pieces obtained by the gel casting method", Journal of the European Ceramic Society, Vol. 25, pp 375-383, (2005).

[20] I. Yamanguchi, S. Lizuka, A. Osaka, H. Monma and J. Tanaka, "The effect of citric acid addition on chitosan/hydroxyapatite composites", Colloids and surfaces A, Vol.214, pp 111-118, (2003).

[21] F.Mc Clune, "International centre for diffraction data", Mineral names, (1982). 
Table 1. Chemicals used and their specifications

\begin{tabular}{|c|c|c|c|c|}
\hline Name & Formula & $\begin{array}{c}\text { M wt. } \\
\mathrm{g} / \text { mole }\end{array}$ & $\begin{array}{c}\text { Grade } \\
\%\end{array}$ & Source \\
\hline $\begin{array}{c}\text { Ammonium } \\
\text { hydroxide }\end{array}$ & $\mathrm{NH}_{4} \mathrm{OH}$ & 35.05 & 99 & $\begin{array}{c}\text { May \& Baker, } \\
\text { England }\end{array}$ \\
\hline $\begin{array}{c}\text { Calcium nitrate } \\
\text { tetrahydrate }\end{array}$ & $\mathrm{Ca}\left(\mathrm{NO}_{3}\right)_{2} .4 \mathrm{H}_{2} \mathrm{O}$ & 236.15 & 98 & $\begin{array}{c}\text { Merck } \\
\text { Germany }\end{array}$ \\
\hline $\begin{array}{c}\text { Di ammonium } \\
\text { hydrogen ortho } \\
\text { phosphate } \\
\text { (anhydrous) }\end{array}$ & $\left(\mathrm{NH}_{4}\right)_{2} \mathrm{HPO}_{4}$ & 132.06 & $\begin{array}{c}\text { Extra } \\
\text { pure }\end{array}$ & $\begin{array}{c}\text { S.D. Fine } \\
\text { Chem. Ltd. } \\
\text { Mumbai }\end{array}$ \\
\hline $\begin{array}{c}\text { Poly vinyl alcohol } \\
\text { (PVAL) }\end{array}$ & $\begin{array}{c}-\left(\mathrm{CH}_{2}-\mathrm{CH}\right)- \\
\mathrm{I} \\
\mathrm{OH}\end{array}$ & $\approx 160000$ & pure & Prolabo. \\
\hline
\end{tabular}




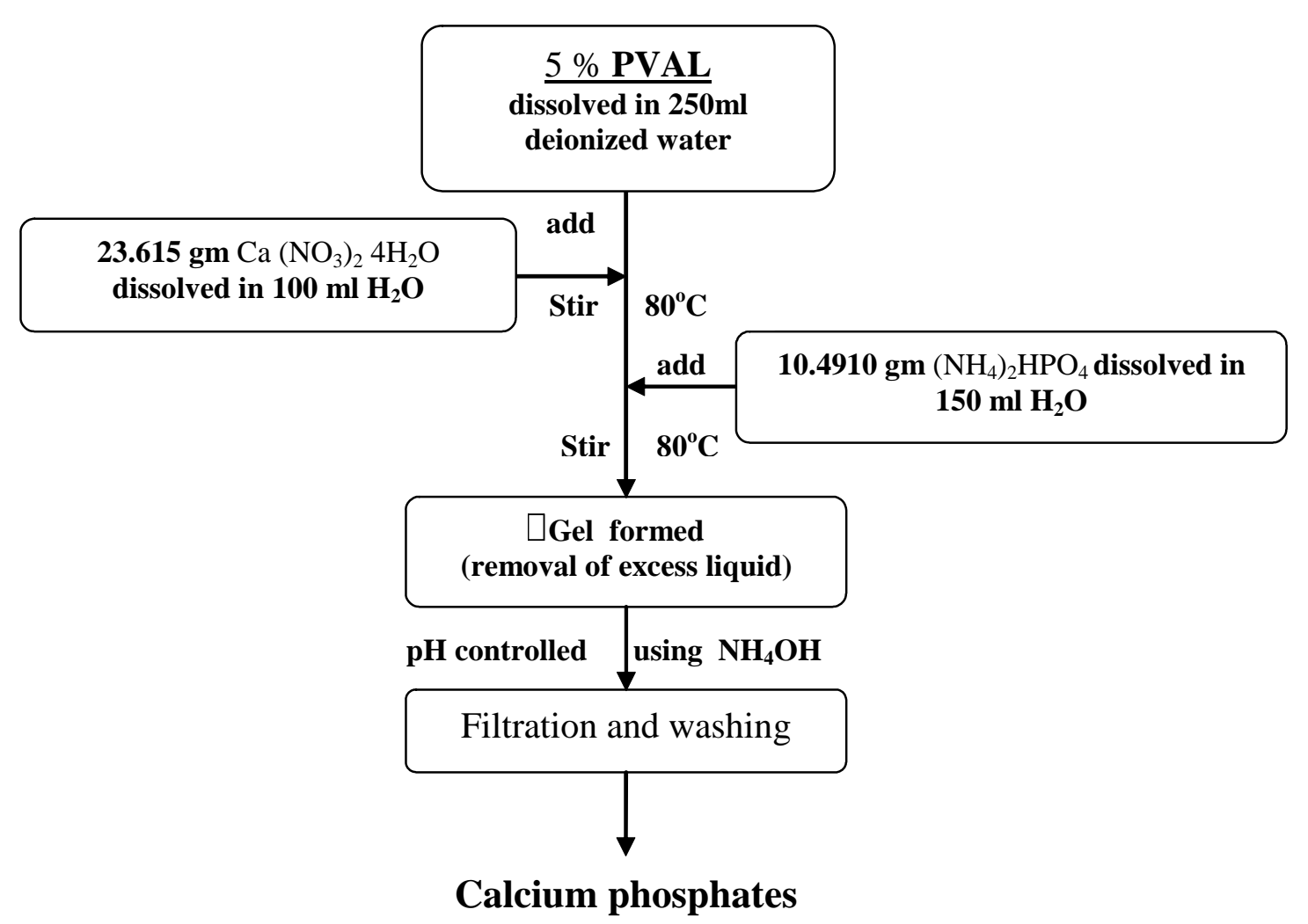

Fig.1. Flow chart for the preparation of calcium phosphate powders prepared by PVAL method 


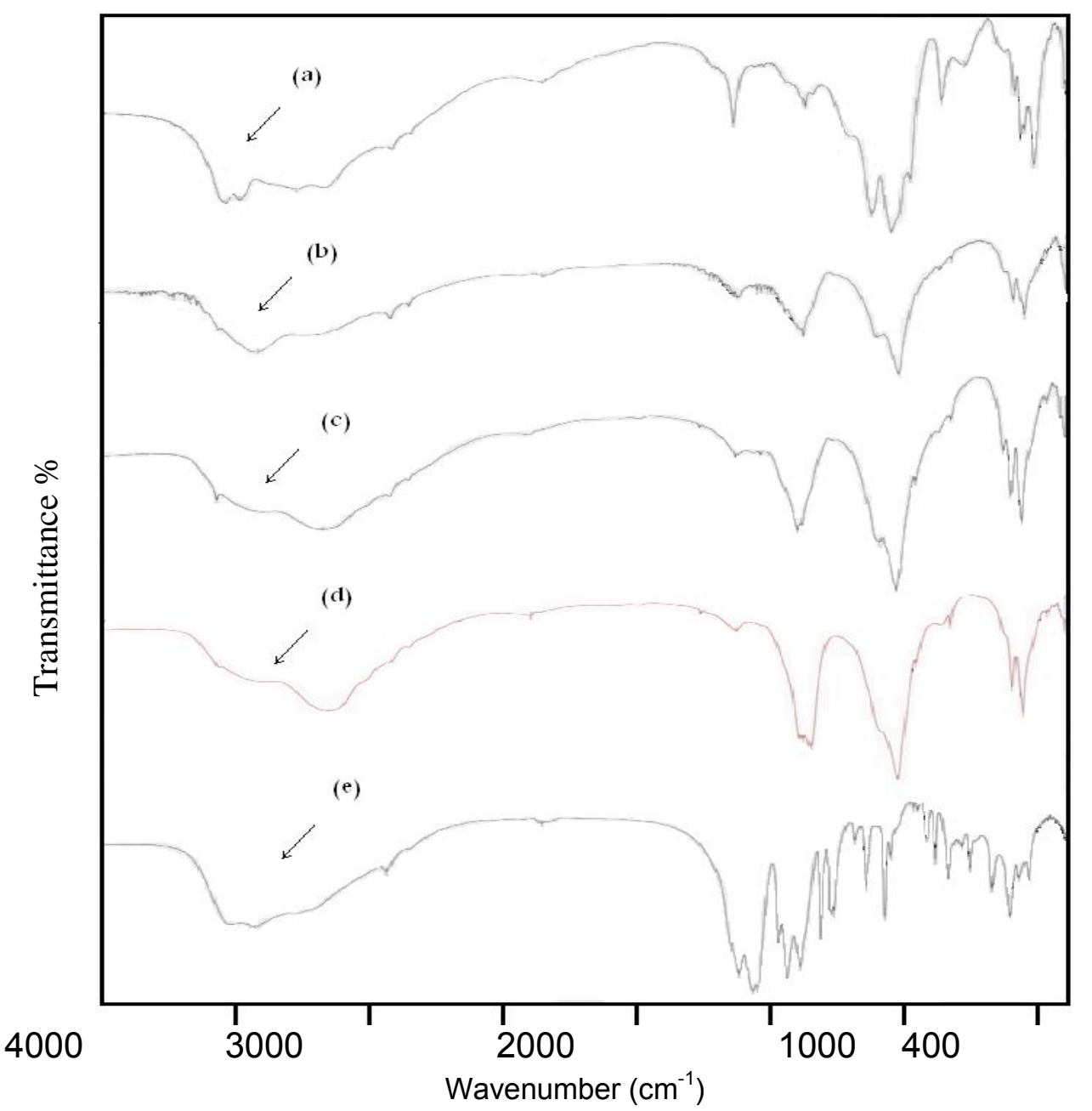

Fig. 2. IR spectra bands of samples prepared via PVA dried at $100^{\circ} \mathrm{C}$ for $24 \mathrm{hr}$ at different pH values (a) 5 (b) 8 (c) 9 (d) 11 and (e) 14

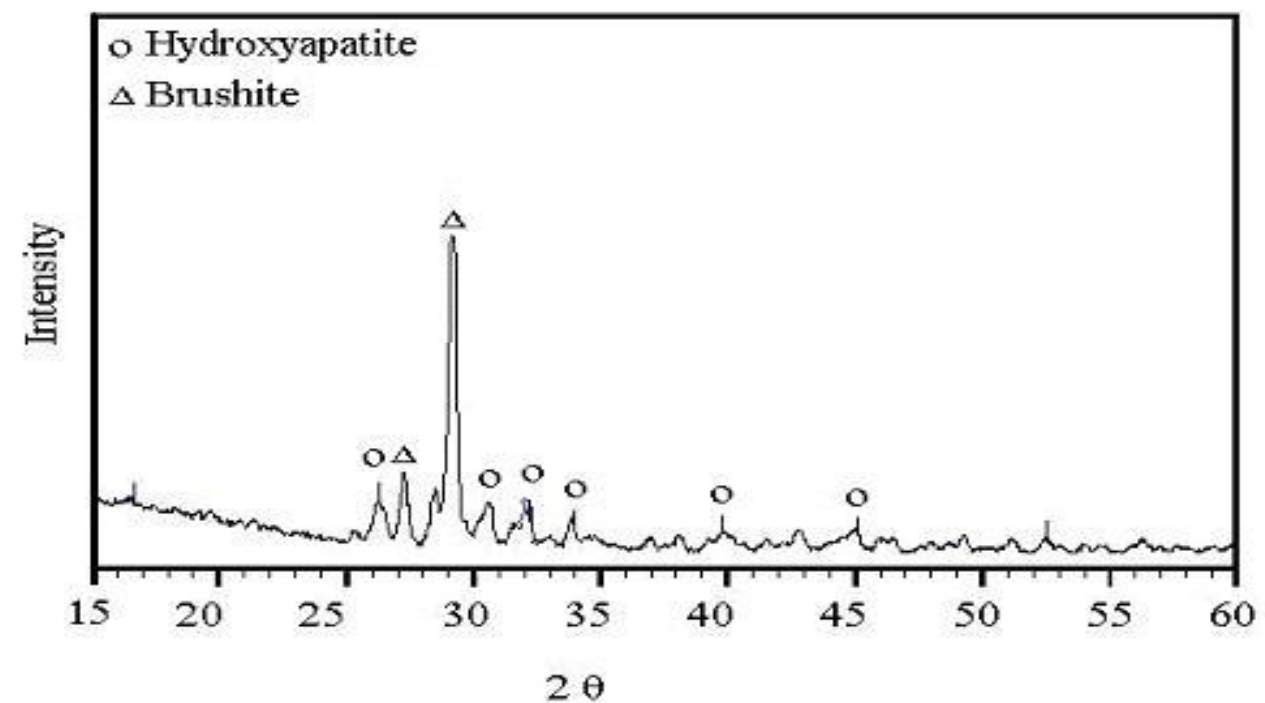

Fig. 3. X-ray diffraction patterns of the sample prepared at $\mathrm{pH} 5$ dried at $100^{\circ} \mathrm{C}$ for $24 \mathrm{hr}$ 


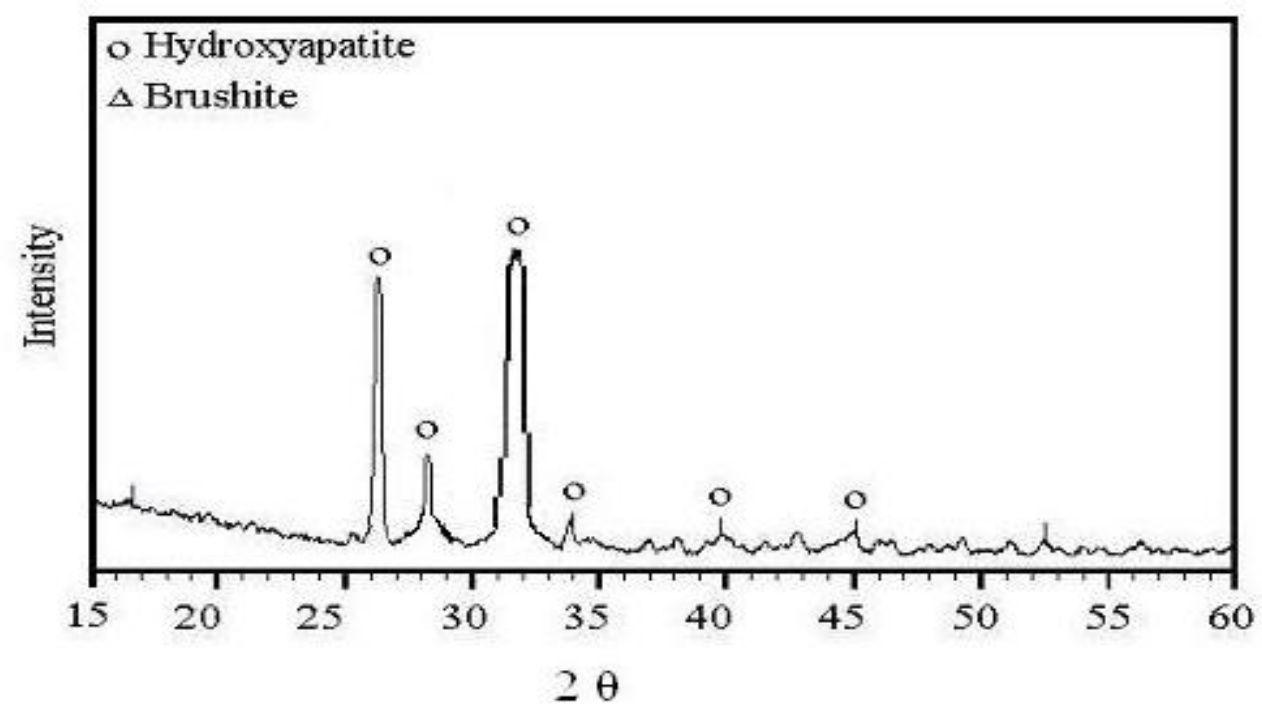

Fig. 4. X-ray diffraction patterns of the sample prepared at $\mathrm{pH} 8$ dried at $100^{\circ} \mathrm{C}$ for $24 \mathrm{hr}$

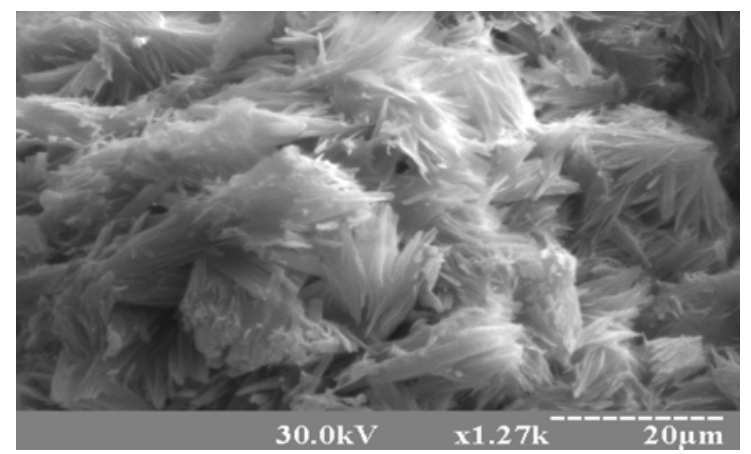

(a)

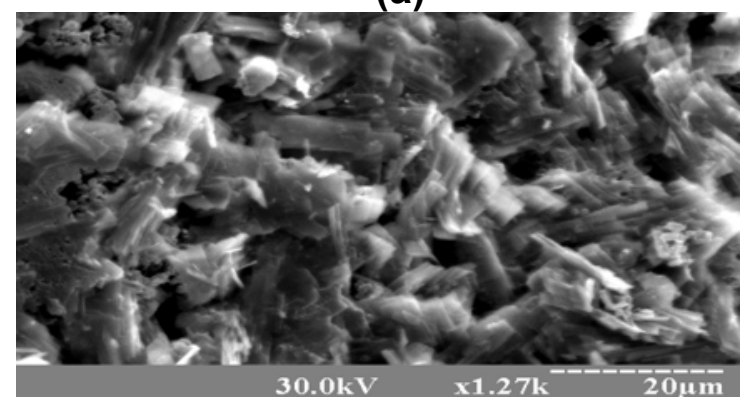

(c)

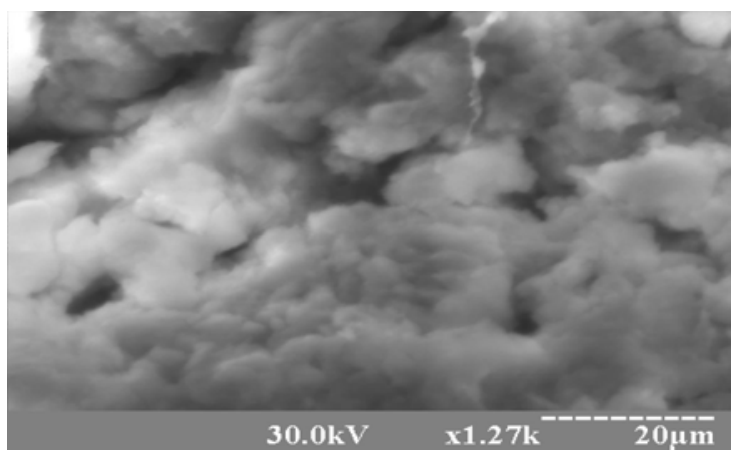

(b)

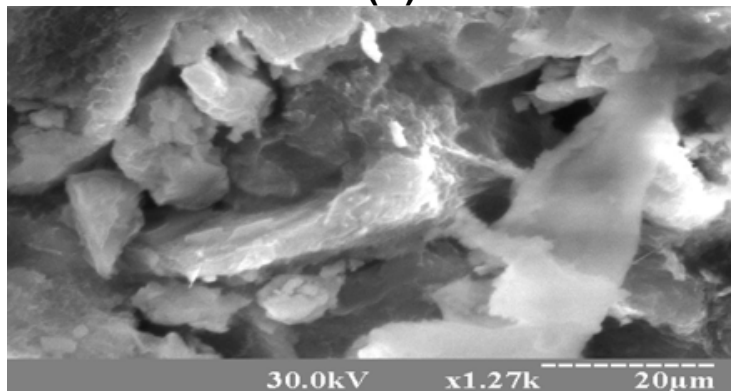

(d)

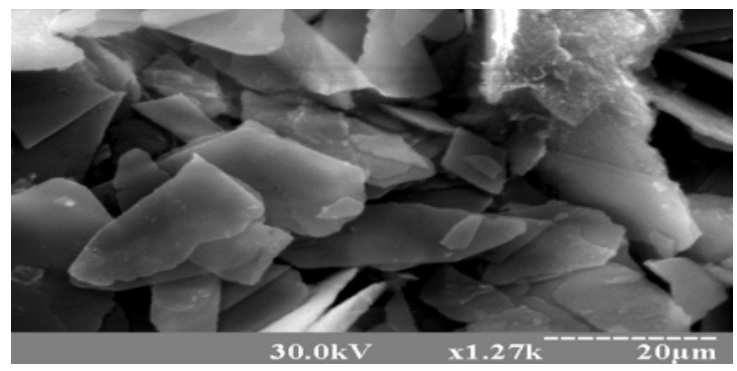

(e)

Fig. 5. Morphology and microstructure of samples prepared via PVAL dried at $100^{\circ} \mathrm{C}$ for $24 \mathrm{hr}$ at different pH values (a) 5, (b) 8, (c) 9, (d) 11 and (e) 14 

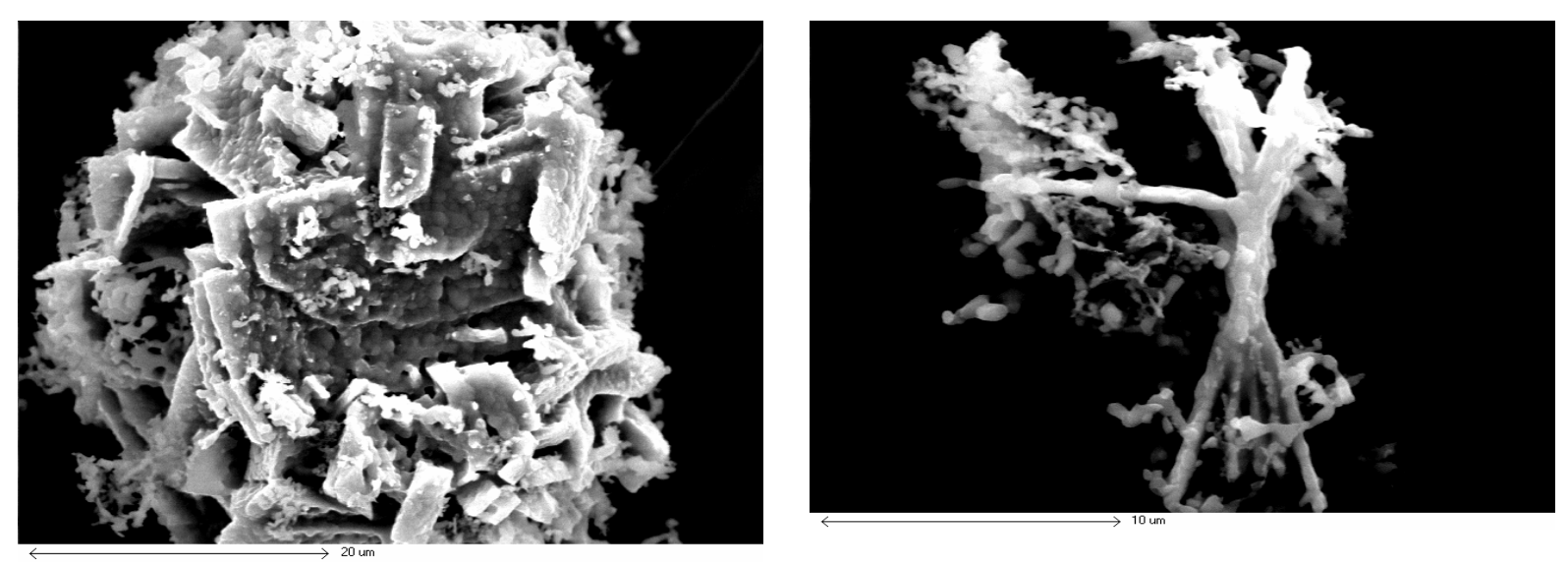

Fig. 6. Morphology and microstructure of the sample prepared at $\mathrm{pH} 8$ and calcined at $900^{\circ} \mathrm{C}$ for $6 \mathrm{hr}$ 